\title{
BUILDING HEALTHY NATIONS THROUGH THEORY OF RELATIVE ECONOMICS FROM THE PHILOSOPHY OF LORD MAHAVIR
}

Dr. V. G. Vadhel, M. P. Arts \& M. H. Commerce College for Women, Ahmedabad, Gujarat, India Dr. Preeti Shah, M. P. Arts \& M. H. Commerce College for Women, Ahmedabad, Gujarat, India Dr. Bharti Dave, M. P. Arts \& M. H. Commerce College for Women, Ahmedabad, Gujarat, India

\author{
dx.doi.org/10.18374/JIMS-14-1.2
}

\begin{abstract}
The world is undergoing a phase of turbulent change. Developing as well as the developed nations are seeing their economy collapsing. Today's economic systems formulated by various scholarly economists have failed to provide the desired results. In this 21 st century we are witnessing malnutrition, poverty, corruption, violence and terrorism, imbalance in environment, big gap between haves and have-nots, difference in urban and rural development and social injustice.H.H. Acharya Mahapragya, has introduced the world with the much needed and highly relevant â€'human- centric' theory of economics. All the principles of â€'human - centric' economics have been derived from the philosophy of Lord Mahavir. This theory is known as the "Theory of Relative Economics" (TRE). This theory is relevant in the present economic condition of the world. It is not only relevant but also that it can be practically implemented with an assurance to provide the desired results and which would lead to a balanced society where the economic growth ensures the growth of each and every individual of the nation. This research paper is a humble attempt to explain the Theory of Relative Economics and suggest the necessary changes in society for a balanced growth of society.
\end{abstract}

Keywords: â€ aparigruh', â€ aatmaupamya', â€位aspaopagraho jeevanam', â€ anekant', â€ samvibhagi' 